\title{
Conducting Polypyrrole Coated Rebar in a Carbonated Concrete Pore Solution: Electrochemical Investigations
}

\author{
H. Munot ${ }^{a}$, P. Deshpande ${ }^{a, *}$ and C. Modhera ${ }^{b}$ \\ ${ }^{a}$ College of Engineering, Pune, 411005, India \\ ${ }^{b}$ Sardar Vallabhbhai National Institute of Technology, Surat, Gujarat, 395007, India
}

Received May 8, 2017; accepted December 8, 2017

\begin{abstract}
Conducting polypyrrole was synthesized, and applied with a paint coating on a low carbon steel sample. By using linear polarization technique, the corrosion rates of uncoated and painted low carbon steel samples, in $3.5 \mathrm{wt} \% \mathrm{NaCl}$, were determined, and found to be 5 mpy and $0.1 \mathrm{mpy}$, respectively. The uncoated and conducting polypyrrole coated steel samples were immersed in a simulated carbonated concrete pore solution, and electrochemical studies were carried out. The shift of corrosion potential in the positive direction implies that the polypyrrole coating gives corrosion protection to low carbon steel, in the anodic direction. As compared to uncoated low carbon samples, polypyrrole coated low carbon steel samples exhibited higher impedance values, but their corrosion resistance decreased with increasing chloride ions in a carbonated pore solution.
\end{abstract}

Keywords: corrosion, carbonated concrete pore solution, rebar and conducting polypyrrole.

\section{Introduction}

Hardened concrete is a composite material composed of coarse and fine aggregates embedded in a matrix of hydrated cement. When cement comes in contact with water, its initial hydration proceeds both inward and outward, in such a manner that the hydrated part gets deposited on the outer periphery, and the dehydrated nucleus of cement gradually diminishes in volume. Consequently, the hardened cement paste has a porous structure which stores a solution containing mainly alkali ions, such as potassium, sodium and hydroxide ions, along with smaller concentrations of calcium and sulphate ions, and others [1-2]. The large hydroxide concentration in the concrete pore solution makes it alkaline ( $\mathrm{pH} ~ 13$ ), forming a protective passive film on the rebar. During final hydration, some of these ions may leave the pore space by leaching, and other ions such as

\footnotetext{
* Corresponding author. E-mail address: pravinpd@ hotmail.com
} 
chloride, sulphate and ammonium may penetrate. In addition, carbon dioxide, either dissolved in water, or as gas from the environment, may penetrate into the pore space [3]. Carbon dioxide reacts with calcium hydroxide in the cement matrix, leading to calcite $\left(\mathrm{CaCO}_{3}\right)$ formation, through the following chemical reactions [4-5]:

$$
\begin{gathered}
\mathrm{Ca}(\mathrm{OH})_{2} \rightarrow \mathrm{Ca}^{2+}(\mathrm{aq})+2 \mathrm{OH}^{-}(\mathrm{aq}) \\
\mathrm{Ca}^{2+}(\mathrm{aq})+2 \mathrm{OH}^{-}(\mathrm{aq})+\mathrm{CO}_{2} \rightarrow \mathrm{CaCO}_{3}+\mathrm{H}_{2} \mathrm{O}
\end{gathered}
$$

The consumption of hydroxyl ions lowers the pore solution's $\mathrm{pH}$ from higher than 12.5 to lower than 9. Subsequently, the passive layer becomes unstable, and the protective passive film on the rebar also gets destroyed due to chloride attack, phenomenon known as chloride induced corrosion. Shin-ichi Miyazato et al. demonstrated that, in the case of chloride induced corrosion, an increase in the water-cement ratio, to approx 0.7 , increased the activity of microcell prominent corrosion. The research team also experienced that a decrease in the watercement ratio, to approx. 0.3, increased the activity of macrocell prominent corrosion. Therefore, they concluded that, in the presence of defects, a high corrosion rate might be promoted, even at a low water-cement ratio.

In the case of carbonation induced corrosion, although macrocell prominent corrosion occurred regardless of the water-cement ratio, the lower was the latter, the lower was the corrosion rate. In this work, it was stated that the corrosion rate induced by chloride was higher than that induced by carbonation [6]. Vladimir Zivica found that initial carbonation intensifies the effect of subsequent chloride attack. In this research, the intensification of a chloride attack due to initial carbonation was attributed to the decreased alkalinity of the concrete pore solution However, initial exposure to chlorides, followed by exposure to the carbonate solution, reduced the corrosion intensity [7]. M. Moreno et al. observed that high levels of carbonate and bicarbonates in the pore solution improved the rebar resistance to localised corrosion. However, pitting corrosion occurred in case of a chloride concentration higher than the critical value [8]. Comprehensive reviews on various methods applied for rebars corrosion protection have been published [9-10]. These methods include cathodic protection, rebar surface treatments, epoxy coating, galvanizing, copper cladding, protective rust growth, surface oxidation, sand blasting, along with the use of admixtures and surface coatings on concrete, high performance concrete, re-alkalization, low water/cement ratio, optimum thickness of concrete cover, and the use of corrosion inhibitors, etc. However, each protection method has its own advantages and limitations. For example, epoxy/zinc duplex coated bars were found to protect steel rebars better than a mixed enamel coating, due to their denser microstructures with isolated pores [11]. But coated rebars are prone to mechanical damage during handling and installation, and to subsequent corrosion. Recently, conducting polymers such as polyaniline and polypyrrole have emerged as non toxic and anticorrosive pigments [12]. The novelty of the conducting polymer based coating is that, in case of damage, the protective film regenerates on the metallic surface, due to redox action. To the best of our knowledge, there are no reports in the 
literature regarding the use of conducting polypyrrole based paint coatings for the protection of reinforced concrete bars. This inspired us to examine the electrochemical behavior of conducting polypyrrole coated steel against chloride ions attack in a carbonated pore solution. The testing results of the coated steel immersed in carbonated pore solutions just after immersion, after 72 hours, 168 hours and 240 hours of immersion are reported in this paper.

\section{Experimental procedure}

\section{Preparation of conducting polypyrrole based paint}

Conducting polypyrrole was synthesized by the method adapted by V. Truong et al. [13]. Conducting polypyrrole based paints were prepared by the method described by P. Deshpande et al. [14], and elaborated as follows: $2 \mathrm{~g}$ of conducting polypyrrole as a pigment, $12 \mathrm{~g}$ of xylene, $8 \mathrm{~g}$ of titanium dioxide $\left(\mathrm{TiO}_{2}\right)$ and $8 \mathrm{~g}$ of bis-(2-ethylhexyl) phthalate (dioctyl phthalate: DOP) were added to $70 \mathrm{~g}$ of the epoxy resin solution (Araldite GY 250 supplied by Huntsman Advanced Materials Pvt Ltd. Andheri (East), Mumbai- 400 093, India). Araldite GY 250 is a universal purpose unmodified medium viscous epoxy resin based on Bisphenol A. Its density is $1.17 \mathrm{~g} / \mathrm{cm}^{3}$, with the epoxy index and epoxy equivalent in the range of $5.30-5.54 \mathrm{eq} / \mathrm{kg}$ and 183-189 g/ eq., respectively. Araldite GY 250 imparts good chemical resistance to the coating, and exhibits excellent mechanical properties. The purpose of adding titanium dioxide and dioctyl phthalate to the epoxy resin was to improve viscosity and elastic properties of the paint. Xylene was used as a solvent for the paint formulation. The mixture was ball milled for $16 \mathrm{~h}$ (Ball mill supplied by Indo German Industries, Daman, India. Drive motor: Crompton Make - 2HP, $1440 \mathrm{rpm}, 415 \mathrm{~V}, 50 \mathrm{~Hz}$ ). The paint was filtered through fine cotton, and applied on the low carbon steel samples (AISI 1015 supplied by Rajasthan steels, Pune, India) by a film applicator, to keep paint thickness $(60 \mu \mathrm{m})$ uniform on the entire surface. Finally, the painted low carbon steel samples were cured in air at ambient temperature for 24 hours.

\section{Preparation of carbonated pore solution}

The electrolyte used for immersion should be an exact representative of the concrete pore solution with $\mathrm{Ca}^{+}, \mathrm{K}^{+}$, and $\mathrm{Na}^{+}$ions addition. In order to study the carbonation effect, a fixed amount of $\mathrm{NaHCO}_{3}(0.2 \mathrm{M})$ was added to each solution [8]. The chemical composition of the simulated concrete pore solution, therefore, is designed as shown in Table 1 [15]. One solution without chloride content, and three separate solutions containing an increasing chloride content $(0.25 \mathrm{M} \mathrm{NaCl}, 0.5$ $\mathrm{M} \mathrm{NaCl}$ and $1 \mathrm{M} \mathrm{NaCl}$ ), were prepared.

Table 1. Chemical composition of the carbonated concrete pore solution.

\begin{tabular}{|l|c|c|}
\hline Compound & Mol.L $^{-1}$ & Weight in g per 100 mL of water \\
\hline $\mathrm{NaOH}$ & 0.1 & 0.4 \\
\hline $\mathrm{KOH}$ & 0.3 & 1.68 \\
\hline $\mathrm{Ca}(\mathrm{OH})_{2}$ & 0.03 & 0.22 \\
\hline $\mathrm{CaSO}_{4} \cdot \mathrm{H}_{2} \mathrm{O}$ & 0.002 & 0.03 \\
\hline $\mathrm{NaHCO}_{3}$ & 0.2 & 1.68 \\
\hline
\end{tabular}




\section{Corrosion studies}

A corrosion cell having three electrode geometry of paint coated samples as working electrode $\left(8 \mathrm{~cm}^{2}\right)$, platinum as counter electrode and a saturated calomel (SCE: pH Products, Hyderabad, India) as reference electrode, was used. The cell was coupled with Gamry reference system 1000 (Wilmington, USA) for linear polarization resistance and electrochemical impedance measurements. All measurements were carried out five times to obtain good reproducibility of the results.

\section{Results and discussion}

\section{Linear polarization resistance}

The samples were polarized, in a $3.5 \mathrm{wt} \% \mathrm{NaCl}$ solution, at about $10 \mathrm{mV}$ from open circuit potential. Scan rate was $0.125 \mathrm{mV} / \mathrm{s}$, as final potential. The corrosion rate was found out using Echem Analyst software (ASTM G 59 -97 reapproved 2003: standard test method for conducting potentiodynamic polarization resistance measurements). Results are recorded in Table 2.

Table 2. Uncoated and coated steel: linear polarization resistance values and corrosion rates.

\begin{tabular}{|c|c|c|c|c|}
\hline Sample & $\begin{array}{c}\mathbf{E}_{\text {corr }} \\
\mathbf{m V}\end{array}$ & $\begin{array}{c}\mathbf{I}_{\text {corr }} \\
\boldsymbol{\mu} \mathbf{A} / \mathbf{c m}^{2}\end{array}$ & $\begin{array}{c}\text { Rp } \\
\text { ohms-cm }^{\mathbf{2}}\end{array}$ & $\begin{array}{c}\text { Corrosion rate } \\
\mathbf{m p y}\end{array}$ \\
\hline Uncoated or bare steel & -631 & 179.9 & 144.8 & 5 \\
\hline Polypyrrole coated low carbon steel & -525 & 2.64 & 9855 & 0.1 \\
\hline
\end{tabular}

The corrosion potential increased from $-631 \mathrm{mV}$, for the uncoated low carbon steel, to $-525 \mathrm{mV}$, for the conducting polypyrrole coated steel sample. The polarization resistance was found to increase from $144.8 \mathrm{ohms}-\mathrm{cm}^{2}$, in the case of bare steel, to $9855 \mathrm{ohms}-\mathrm{cm}^{2}$, in the case of polypyrrole coated steel. The corrosion rate was significantly reduced, due to a decrease in the current density from $179.9 \mu \mathrm{A} / \mathrm{cm}^{2}$ to $2.64 \mu \mathrm{A} / \mathrm{cm}^{2}$. The corrosion rate of the conducting polypyrrole coated low carbon steel was found to be $0.1 \mathrm{mpy}$, which is about 50 times lower than that of unpainted low carbon steel. A shift of $106 \mathrm{mV}$ in the value of the corrosion potential in the positive direction indicates that the coating imparts corrosion protection to low carbon steel in a $3.5 \mathrm{wt} \% \mathrm{NaCl}$ solution, by preventing cathodic reduction processes, i.e., by anodic protection.

\section{Electrochemical impedance}

Electrochemical impedance measurements were carried out for uncoated and polypyrrole coated low carbon steel samples immersed in a carbonated chloride free concrete pore solution, and in a carbonated concrete pore solution containing fixed amounts of chlorides. The results of these studies are herein reported in terms of Bode plots. Figs. 1 and 2 show, respectively, the Bode plot of the uncoated low carbon steel sample just after immersion in a carbonated pore solution, and after 72 hours of immersion in a pore solution, as a function of $\mathrm{NaCl}$ concentrations. 


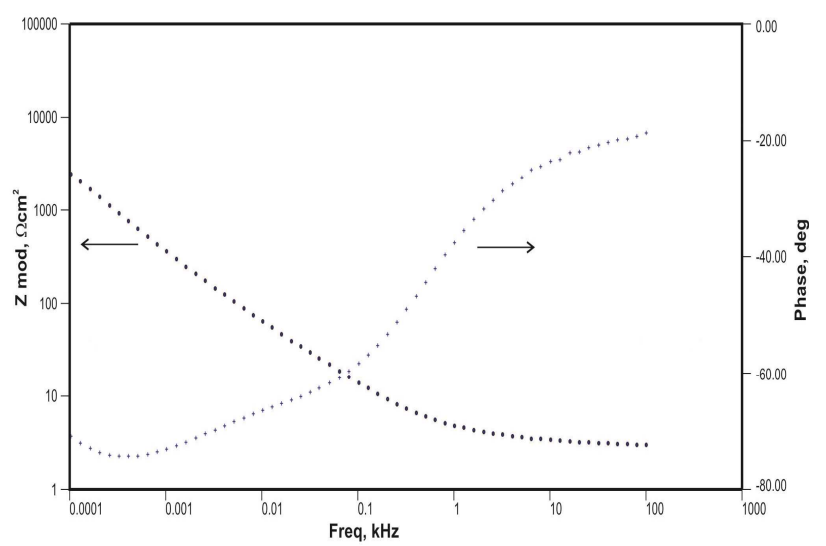

Figure 1. Bode plot of uncoated steel just after immersion in a carbonated pore solution.

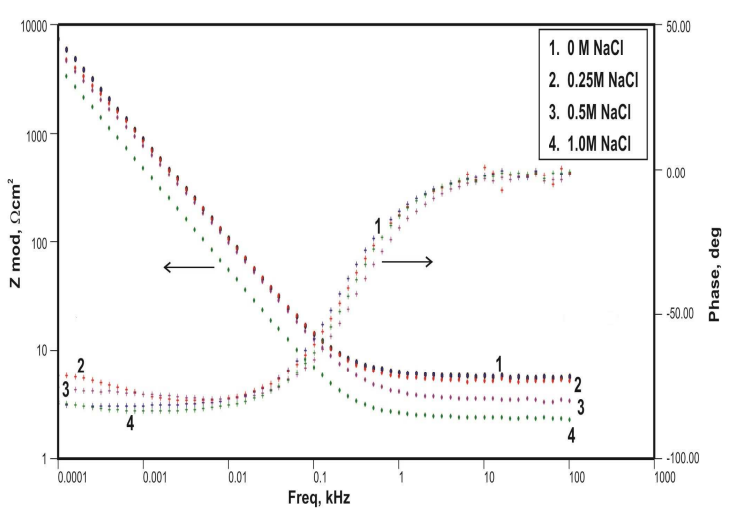

Figure 2. Bode plot of uncoated steel immersed for 72 hours in a carbonated pore solution.

These plots are analyzed using the equivalent circuit shown in Fig. 3; the corresponding impedance $\left(Z_{\text {mod }}\right)$, coating resistance $\left(R_{C}\right)$ and coating capacitance $\left(\mathrm{C}_{\mathrm{C}}\right)$ values, except solution resistance $\left(\mathrm{R}_{\mathrm{U}}\right)$, obtained by modelling these figures, are recorded in Tables 3, 4 and 5 .

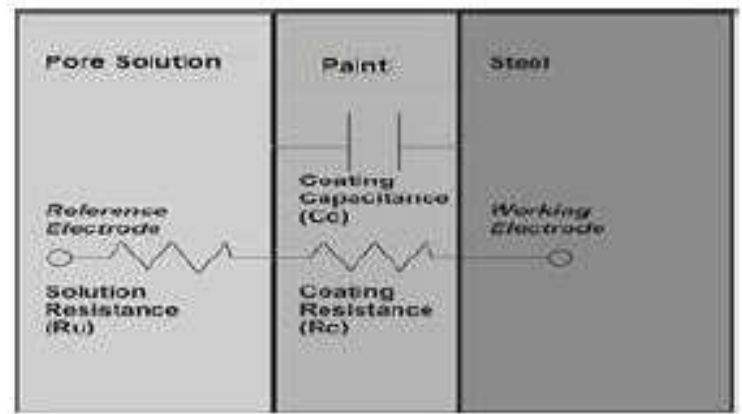

Figure 3. Equivalent circuit used for modelling impedance behaviour.

The equivalent circuit shown in Fig. 3 is Randles circuit. Randles circuit, a combination of resistor and capacitor, not only can be used to model non coated metals, but also coated metals. When this circuit is used to model electrochemical processes in the case of non-coated steel, the resistance of the 
metal to polarization and the capacitance associated with the formation of a double layer are expressed in terms of polarization resistance $\left(R_{p}\right)$ and double layer capacitance $\left(\mathrm{C}_{\mathrm{dl}}\right)$, respectively. In the case of coated steel, which was modeled using the same circuit, these terms are replaced by coating resistance $\left(\mathrm{R}_{\mathrm{c}}\right)$ and coating capacitance $\left(\mathrm{C}_{\mathrm{c}}\right)$, respectively.

Table 3. Uncoated bar: impedance values.

\begin{tabular}{|c|c|c|c|c|c|}
\hline \multirow{3}{*}{$\begin{array}{c}\text { Sr } \\
\text { no }\end{array}$} & \multirow{3}{*}{$\begin{array}{l}\text { Sodium chloride } \\
\text { concentration }\end{array}$} & \multicolumn{4}{|c|}{$\mathrm{Zmod}, \mathrm{K} \Omega-\mathrm{cm}^{2}$} \\
\hline & & \multicolumn{4}{|c|}{ Immersion time } \\
\hline & & $0 \mathrm{hrs}$ & $72 \mathrm{hrs}$ & $168 \mathrm{hrs}$ & $240 \mathrm{hrs}$ \\
\hline 1 & Without $\mathrm{NaCl}$ & 2.45 & 6.33 & 6.18 & 5.32 \\
\hline 2 & $0.25 \mathrm{M} \mathrm{NaCl}$ & 2.45 & 5.43 & 5.31 & 3.44 \\
\hline 3 & $0.5 \mathrm{M} \mathrm{NaCl}$ & 2.45 & 5.4 & 4.59 & 2.86 \\
\hline 4 & $1 \mathrm{M} \mathrm{NaCl}$ & 2.45 & 3.9 & 2.40 & 1.98 \\
\hline
\end{tabular}

Table 4. Uncoated bar: coating resistance.

\begin{tabular}{|c|c|c|c|c|c|}
\hline \multirow{2}{*}{$\begin{array}{c}\text { Sr. } \\
\text { no }\end{array}$} & \multirow{3}{*}{$\begin{array}{c}\text { Sodium chloride } \\
\text { concentration }\end{array}$} & \multicolumn{4}{|c|}{$\mathbf{R}_{\mathbf{C}}\left(\mathbf{K} \Omega-\mathbf{c m}^{2}\right)$} \\
\cline { 3 - 6 } & & $0 \mathrm{hr}$ & $72 \mathrm{hrs}$ & $168 \mathrm{hrs}$ & $240 \mathrm{hrs}$ \\
\hline 1 & Without $\mathrm{NaCl}$ & 0.58 & 27.80 & 13.38 & 8.5 \\
\hline 2 & $0.25 \mathrm{M} \mathrm{NaCl}$ & 0.58 & 16.13 & 9.87 & 7.58 \\
\hline 3 & $0.5 \mathrm{M} \mathrm{NaCl}$ & 0.58 & 11.85 & 6.03 & 5.19 \\
\hline 4 & $1 \mathrm{M} \mathrm{NaCl}$ & 0.58 & 10.36 & 5.73 & 1.60 \\
\hline
\end{tabular}

Table 5. Uncoated bar: coating capacitance.

\begin{tabular}{|c|c|c|c|c|c|}
\hline \multirow{2}{*}{$\begin{array}{c}* \\
\text { Sr. }\end{array}$} & \multirow{2}{*}{$\begin{array}{c}\text { Sodium chloride } \\
\text { no }\end{array}$} & \multirow{4}{*}{$\mathbf{C}_{\mathbf{C}}(\boldsymbol{\mu} \mathbf{F})$} \\
\cline { 3 - 6 } & & \multicolumn{4}{|c|}{ Immersion time } \\
\cline { 3 - 6 } & $0 \mathrm{hr}$ & 72 & $168 \mathrm{hrs}$ & $240 \mathrm{hrs}$ \\
\hline 1 & Without $\mathrm{NaCl}$ & 431 & 168 & 200 & 325 \\
\hline 2 & $0.25 \mathrm{M} \mathrm{NaCl}$ & 431 & 174 & 212 & 368 \\
\hline 3 & $0.5 \mathrm{M} \mathrm{NaCl}$ & 431 & 182 & 308 & 440 \\
\hline 4 & $1 \mathrm{M} \mathrm{NaCl}$ & 431 & 185 & 315 & 559 \\
\hline
\end{tabular}

Figs. 4 and 5 show Bode plots of the uncoated sample for, respectively, 168 hours and 240 hours of immersion in a pore solution, as a function of $\mathrm{NaCl}$ concentration.

In the uncoated steel sample case, the impedance $\left(Z_{\text {mod }}\right)$ increased from $2.45 \mathrm{~K} \Omega$ $\mathrm{cm}^{2}$ to $6.33 \mathrm{~K} \Omega-\mathrm{cm}^{2}$, from just after immersion, to the end of 72 hours of immersion, in a pore solution without $\mathrm{NaCl}$.

The relevant phase angle - log frequency diagram - was found to increase at minimum frequency region. This can be assigned to initial passive film formation on the rebar. These results are in good agreement with recent work [16]. However, the phase angle value decreased to $6.18 \mathrm{~K} \Omega-\mathrm{cm}^{2}$ and $5.32 \mathrm{~K} \Omega-\mathrm{cm}^{2}$, at the end of 168 hours and 240 hours of immersion, respectively, at minimum frequency region. This can be attributed to the passive film damage in 
carbonation, due to $\mathrm{NaHCO}_{3}$ addition. It has been noted that the impedance values decreased from $6.33 \mathrm{~K} \Omega-\mathrm{cm}^{2}$ to $5.43 \mathrm{~K} \Omega-\mathrm{cm}^{2}, 5.4 \mathrm{~K} \Omega-\mathrm{cm}^{2}$, and $3.9 \mathrm{~K} \Omega-$ $\mathrm{cm}^{2}$, in a pore solution with increasing chloride contents from $0.25 \mathrm{M} \mathrm{NaCl}$ to $1 \mathrm{M}$ $\mathrm{NaCl}$, respectively, at the end of 72 hours of immersion.

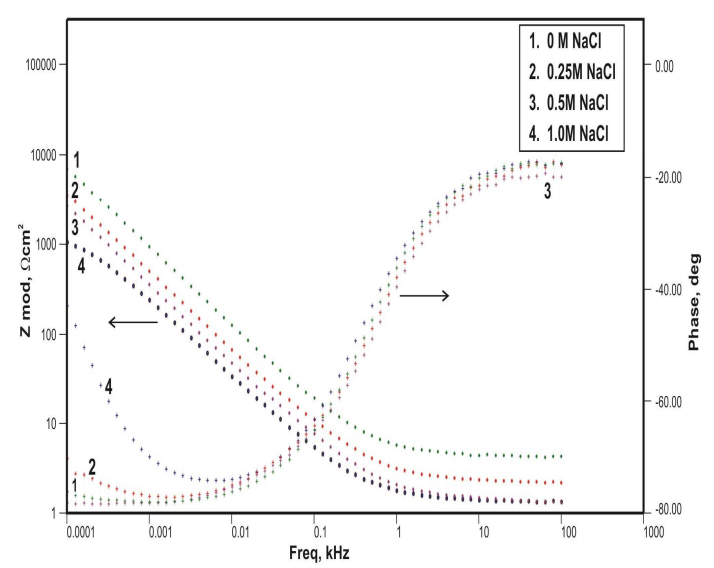

Figure 4. Bode plot of uncoated steel immersed for 168 hours in a carbonated pore solution.

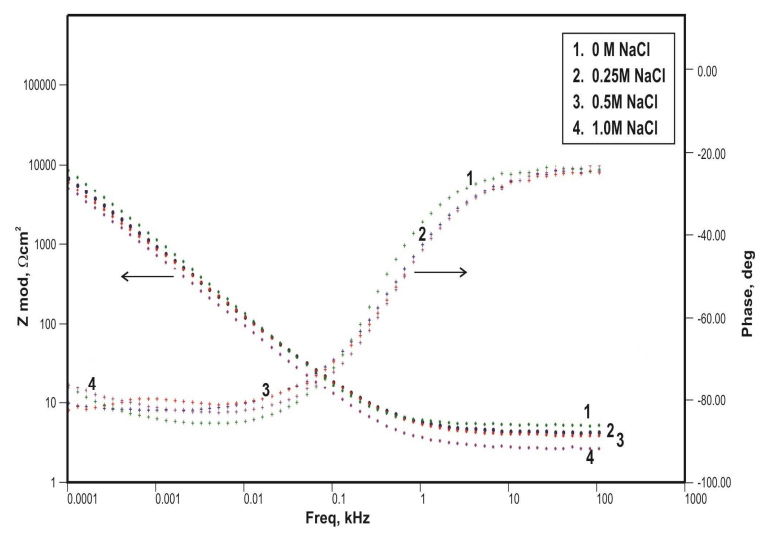

Figure 5. Bode plot of uncoated steel immersed for 240 hours in a carbonated pore solution.

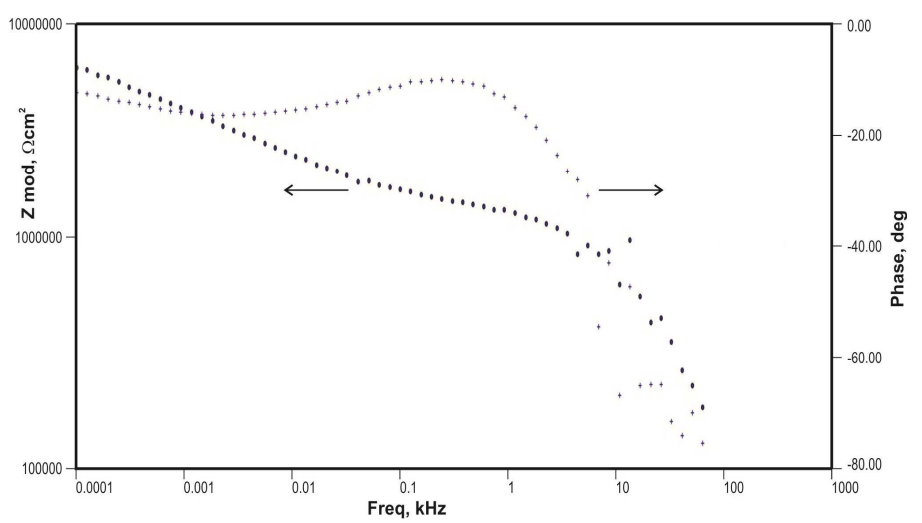

Figure 6. Bode plot of Polypyrrole coated steel just after immersion in a carbonated pore solution. 
The impedance, after 168 hours of immersion in the pore solution, decreased from $6.18 \mathrm{~K} \Omega-\mathrm{cm}^{2}$ up to $5.31 \mathrm{~K} \Omega-\mathrm{cm}^{2}, 4.59 \mathrm{~K} \Omega-\mathrm{cm}^{2}$ and $2.40 \mathrm{~K} \Omega-\mathrm{cm}^{2}$, with increasing chloride contents from $0.25 \mathrm{M} \mathrm{NaCl}$ to $1 \mathrm{M} \mathrm{NaCl}$, respectively. By the end of 240 hours of immersion, the impedance decreased from $5.32 \mathrm{~K} \Omega-\mathrm{cm}^{2}$ to $3.44 \mathrm{~K} \Omega-\mathrm{cm}^{2}$, $2.86 \mathrm{~K} \Omega-\mathrm{cm}^{2}$ and $1.98 \mathrm{~K} \Omega-\mathrm{cm}^{2}$, respectively, with increasing chloride contents from $0.25 \mathrm{M} \mathrm{NaCl}$ to $1 \mathrm{M} \mathrm{NaCl}$, respectively.

The Bode plots for the polypyrrole coated steel sample, just after immersion in the pore solution, after 72 hours, 168 hours and 240 hours of immersion are shown in Figs. 6 to 9, respectively.

Fig. 7 shows impedance values of the coated steel sample after 72 hours of immersion in the pore solution, as a function of $\mathrm{NaCl}$ concentrations.

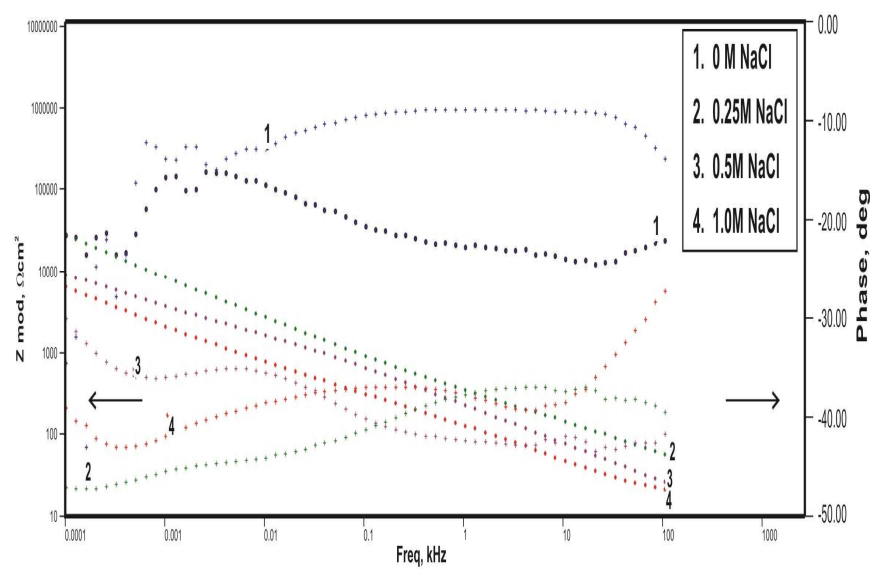

Figure 7. Bode plot of polypyrrole coated steel immersed in a carbonated pore solution for 72 hours.

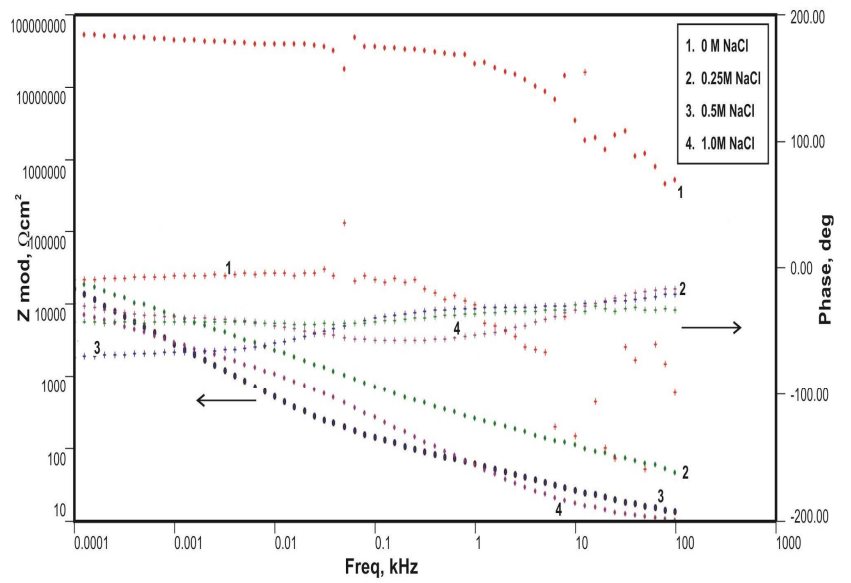

Figure 8. Bode plot of polypyrrole coated steel immersed for 168 hours in a pore solution.

Figs. 8 and 9 show the impedance values of the coated sample with 168 and 240 hours of immersion time, as functions of $\mathrm{NaCl}$ concentrations, respectively. 


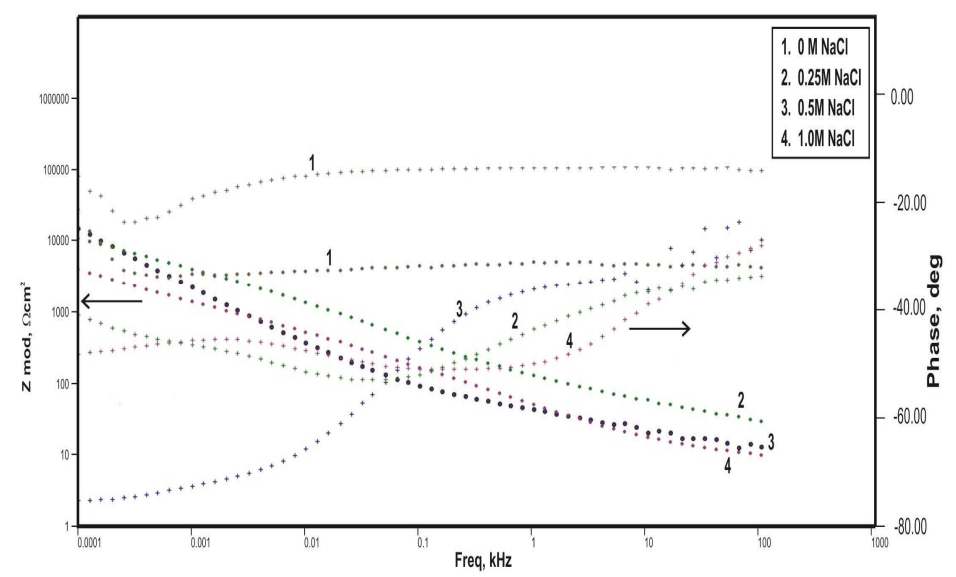

Figure 9. Bode plot of polypyrrole coated steel immersed for 240 hours in a pore solution.

The impedance values $\left(Z_{\text {mod }}\right)$, coating resistance $\left(R_{C}\right)$ and coating capacitance $\left(C_{C}\right)$ are obtained by using the equivalent electrical circuit shown in Fig. 5, and recorded in Tables 6, 7 and 8, respectively.

Table 6. Polypyrrole coated steel: impedance values.

\begin{tabular}{|c|c|c|c|c|c|}
\hline \multirow{3}{*}{$\begin{array}{c}\text { Sr. } \\
\text { no }\end{array}$} & \multirow{3}{*}{$\begin{array}{c}\text { Sodium } \\
\text { chloride } \\
\text { concentration }\end{array}$} & \multicolumn{4}{|c|}{$\mathrm{Z} \bmod , \mathrm{K} \Omega-\mathrm{cm}^{2}$} \\
\hline & & \multicolumn{4}{|c|}{ Immersion time } \\
\hline & & $0 \mathrm{hrs}$ & $72 \mathrm{hrs}$ & 168 & 240 \\
\hline 1 & Without $\mathrm{NaCl}$ & 42.38 & 59 & 42.96 & 53.74 \\
\hline 2 & $0.25 \mathrm{M} \mathrm{Na} \mathrm{Cl}$ & 42.38 & 11.75 & 16.42 & 24.81 \\
\hline 3 & $0.5 \mathrm{M} \mathrm{Na} \mathrm{Cl}$ & 42.38 & 6.05 & 4.79 & 2.9 \\
\hline 4 & $1 \mathrm{M} \mathrm{NaCl}$ & 42.38 & 5.66 & 3.05 & 2.33 \\
\hline
\end{tabular}

Table 7. Polypyrrole coated steel: coating resistance.

\begin{tabular}{|c|c|c|c|c|c|}
\hline \multirow{3}{*}{$\begin{array}{l}\text { Sr. } \\
\text { no }\end{array}$} & \multirow{3}{*}{$\begin{array}{c}\text { Sodium } \\
\text { chloride } \\
\text { concentration }\end{array}$} & \multicolumn{4}{|c|}{$\mathrm{R}_{\mathrm{C}} \mathrm{K} \Omega-\mathrm{cm}^{2}$} \\
\hline & & \multicolumn{4}{|c|}{ Immersion time } \\
\hline & & $0 \mathrm{hrs}$ & $72 \mathrm{hrs}$ & 168 & 240 \\
\hline 1 & Without $\mathrm{NaCl}$ & 4.32 & 32.59 & 24.19 & 28.9 \\
\hline 2 & $0.25 \mathrm{M} \mathrm{NaCl}$ & 4.32 & 18.9 & 10.32 & 8.49 \\
\hline 3 & $0.5 \mathrm{M} \mathrm{NaCl}$ & 4.32 & 15.7 & 6.92 & 6.37 \\
\hline 4 & $1 \mathrm{M} \mathrm{NaCl}$ & 4.32 & 13.2 & 6.48 & 2.98 \\
\hline
\end{tabular}

Table 8. Polypyrrole coated steel: coating capacitance.

\begin{tabular}{|c|c|c|c|c|c|}
\hline \multirow{3}{*}{$\begin{array}{c}* \\
\text { Sr. }\end{array}$} & \multirow{2}{*}{$\begin{array}{c}\text { Sodium } \\
\text { no }\end{array}$} & \multicolumn{4}{|c|}{$\mathbf{C}_{\mathbf{C}}(\boldsymbol{\mu} \mathbf{\mu})$} \\
\cline { 3 - 6 } concentride \\
\cline { 3 - 6 } & & \multicolumn{4}{|c|}{ Immersion time } \\
\cline { 3 - 6 } & $0 \mathrm{hrs}$ & $72 \mathrm{hrs}$ & 168 & 240 \\
\hline 2 & Without NaCl & 0.36 & 0.1 & 0.5 & 0.3 \\
\hline 3 & $0.25 \mathrm{M} \mathrm{NaCl}$ & 0.36 & 1.37 & 1.48 & \\
\hline 4 & $0.5 \mathrm{M} \mathrm{NaCl}$ & 0.36 & 4 & 43.65 & \\
\hline
\end{tabular}


As compared to the uncoated low carbon steel sample, polypyrrole coated low carbon steel sample exhibited higher impedance $\left(Z_{\bmod }\right), \sim 42.38 \Omega-\mathrm{cm}^{2}$, higher coating resistance $\left(\mathrm{R}_{\mathrm{C}}\right), \sim 4.32 \mathrm{~K} \Omega-\mathrm{cm}^{2}$, and lower capacitance $\left(\mathrm{C}_{\mathrm{C}}\right), \sim 0.36 \mu \mathrm{F}$, just after immersion. By the end of 72 hours of immersion, it was seen a significant increase in impedance $\left(\mathrm{Z}_{\mathrm{mod}}\right), \sim 59 \Omega-\mathrm{cm}^{2}$, and coating resistance $\left(\mathrm{R}_{\mathrm{C}}\right), \sim 32.59 \mathrm{~K} \Omega-\mathrm{cm}^{2}$, and a reduction in capacitance $\left(\mathrm{C}_{\mathrm{C}}\right), \sim 0.1 \mu \mathrm{F}$. Higher impedance, coating resistance, and lower coating capacitance values can be attributed to the protective nature of conducting polypyrrole as a pigment [12]. In the relevant phase angle - log frequency diagram, the phase angle value was found to increase at minimum frequency region, which can be attributed to the protection offered by the conducting polypyrrole based epoxy coating. Water molecules and chloride ion species penetrate into the coating as a function of immersion time. This is reflected in the lowering of impedance and coating resistance values, with an associated increase in the coating capacitance, as a function of time during immersion in a pore solution up to 168 hours. In the corresponding phase angle log frequency diagram, the phase angle value showed a tendency to decrease at minimum frequency region, due to the loss of corrosion protection. Subsequently, impedance $\left(\mathrm{Z}_{\mathrm{mod}}\right)$ and coating resistance $\left(\mathrm{R}_{\mathrm{C}}\right)$ increased to the level of $\sim 53.74 \mathrm{~K} \Omega-\mathrm{cm}^{2}$ and $28.9 \mathrm{~K} \Omega-\mathrm{cm}^{2}$, respectively, by the end of 240 hours of immersion, and the phase angle value was again found to increase. This can be assigned to the self healing effect of conducting polypyrrole as a pigment $[12,17]$. However, it must be noted that the impedance $\left(\mathrm{Z}_{\bmod }\right)$ and coating resistance $\left(R_{C}\right)$ values decreased, and coating capacitance $\left(C_{C}\right)$ increased with higher chloride contents up to $1 \mathrm{M} \mathrm{NaCl}$. By the end of 240 hours of immersion, polypyrrole coated steel exhibited the lowest impedance $\left(Z_{\text {mod }}\right)$, $\sim 2.33 \Omega-\mathrm{cm}^{2}$, the lowest coating resistance $\left(\mathrm{R}_{\mathrm{C}}\right), \sim 2.98 \mathrm{~K} \Omega-\mathrm{cm}^{2}$, and the highest capacitance $\left(\mathrm{C}_{\mathrm{C}}\right), \sim 511.1 \mu \mathrm{F}$ values. Thus, it can be said that the corrosion resistance of polypyrrole coated steel decreased with increasing chloride contents in a carbonated pore solution.

\section{Conclusions}

The corrosion rate of conducting polypyrrole coated low carbon steel was found to be $0.1 \mathrm{mpy}$, which is about 50 times lower than that of unpainted low carbon steel. A shift of $106 \mathrm{mV}$ in the value of the corrosion potential in the positive direction indicates that the coating imparts corrosion protection to low carbon steel in a $3.5 \mathrm{wt} \% \mathrm{NaCl}$ solution by anodic protection. The passive film formed on an uncoated rebar gets damaged due to the addition of $\mathrm{NaHCO}_{3}$, after 72 hours of immersion. Higher impedance values, higher coating resistance and lower coating capacitance, in the case of conducting polypyrrole coated low carbon steel, can be attributed to the protective nature of that polymer. An initial lowering of impedance values, with an associated increase in the coating capacitance up to 168 hours, followed by an increase in those values, with a decrease in the coating capacitance, by the end of 240 hours of immersion, can be assigned to the self healing effect of conducting polypyrrole. However, corrosion resistance of polypyrrole coated steel decreased with increasing chloride 
contents in a carbonated pore solution.

\section{Acknowledgments}

The authors thank Prof. N.B. Dhokey, Head, Department of Metallurgy and Materials Science, College of Engineering, Pune (M.S.), India, for providing facilities, and Prof. B. B. Ahuja, Director, College of Engineering, Pune (M.S.), India, for his encouragement.

\section{References}

1. Gambhir ML. Concrete Technology. Tata McGraw Hill; 2004.

2. Mehata PK, Monteiro PJM. Concrete Microstructure, properties and materials. New York: McGraw-Hill; 2014.

3. Wan X, Wittmann FH, Zhao T, et al. Appl Phys Eng. 2013;14:71.

4. Zhou Y, Gencturk B, Willam K, et al. J Mater Civil Eng. 2014;28:1943.

5. Suba U, Srinivasan P, Sakthieswaran N. Int J Res Appl Sci Eng Tech. 2016;4:647.

6. Miyazato S, Otsuki N. J Adv Concrete Technol. 2010;8:135.

7. Zivica V. Bull. Mater Sci. 2003;26:605.

8. Moreno M, Morris W, Alvarez MG, et al. Corrosion Sci. 2004;46:2699.

9. Chung DDL. J Mater Eng Perform. 2000;9:585.

10. Kumar V. Corros Rev. 1998;16:317.

11 Tang F, Chen G, Brow RK, et al. Corros Sci. 2012;59:157.

12. Deshpande P, Sazou D. Corrosion Protection of Metals by Intrinsically Conducting Polymers. Boca Raton: CRC Press; 2015.

13. Truong V, Lai P, Moore B, et al. Synthetic Metals. 2000;110:7.

14. Deshpande P, Vagge S, Jagtap S, et al. Protect Metals Phys Chem Surf. 2012;48:356.

15. Poursaee A. Concrete Res Lett. 2010;1:90.

16. Williamson J, Isgor OB. Corros Sci. 2016;106:82.

17. Ohsuka T. Int J Corros. 2012;4:915090. 